\title{
Effect of a sleep education program on sleep knowledge and habits in elementary and high school teachers
}

Jane Carla de Souza. Faculdade de Ciências da Saúde do Trairi.

Sabinne Danielle Galina. Universidade Federal do Rio Grande do Norte.

Ivanise Cortez de Sousa. Universidade Federal do Rio Grande do Norte.

Carolina Virginia Macêdo de Azevedo. Universidade Federal do Rio Grande do Norte.

\begin{abstract}
The influence of a sleep education program (SEP) on the knowledge, habits, quality of sleep, and daytime sleepiness was evaluated in 40 Brazilian elementary and high school teachers [Groups: Experimental $(E G=26) / C o n t r o l(C G=14)]$. The Health and Sleep questionnaire, Pittsburgh Sleep Quality Index and sleep logs were applied to both groups, at baseline and in reassessment three weeks after a SEP with the EG. The methodology of the SEP was based on the Meaningful Learning theory proposed by Ausubel, consisting of four fortnightly meetings, lasting $4 \mathrm{~h}$ each. After the program, the EG showed an increase in sleep knowledge and a reduction in coffee consumption near bedtime. Besides, $17 \%$ of teachers improved sleep quality in this group. However, no changes occurred in sleep schedules and sleepiness. Nevertheless, the positive results reinforce the need for sleep education programs with teachers to spread sleep knowledge in schools and improve the sleep quality in these professionals.
\end{abstract}

Keywords: sleep education; sleep quality; daytime sleepiness; teachers; health promotion.

\section{Resumo}

Efeito de um programa de educação sobre o sono no conhecimento e hábitos de sono em professores do ensino fundamental e médio. A influência de um programa de educação sobre o sono (PES) nos conhecimentos, hábitos e qualidade do sono, e sonolência diurna foi avaliada em 40 professores brasileiros do ensino básico [Grupos: Experimental (GE=26)/Controle (GC=14)]. A Saúde e Sono, o Índice de Qualidade de Sono de Pittsburgh e o diário de sono foram aplicados nos grupos antes e três semanas após um PES aplicado no GE. O programa baseado na teoria da Aprendizagem Significativa consistiu de quatro encontros de $4 \mathrm{~h} / \mathrm{cada}$. Após o programa, o GE aumentou os conhecimentos sobre sono e reduziu o relato de consumo de café próximo a dormir, com melhora na qualidade de sono em 17\% dos professores. Embora não tenha havido diferenças nos horários de sono e sonolência, os resultados positivos reforçam a necessidade do desenvolvimento de programas educacionais sobre sono com professores para difusão do assunto nas escolas e melhora da qualidade do sono nestes profissionais.

Palavras-chaves: educação sobre o sono; qualidade de sono; sonolência diurna; professores; promoção da saúde.

\section{Resumen}

Efecto de un programa de educación sobre el sueño en el conocimiento y hábitos del sueño de los maestros. La influencia de un programa de educación sobre el sueño (PES) en los conocimientos, hábitos, calidad de sueño y somnolencia diurna fue evaluado en 40 maestros brasileños de educación básica [Grupos: Experimental (GE=26)/Control (GC=14)]. Los cuestionarios Salud y Sueño, Índice de calidad de sueño de Pittsburgh y diario del sueño se aplicaron en los grupos, antes y tres semanas después de un PES en el GE. El programa basado en la teoría del aprendizaje significativo consistió en cuatro sesiones de 4 horas/cada uno. Después del programa, el GE aumentó su conocimiento sobre el sueño y hubo una reducción en el consumo de café cerca de la hora de acostarse, con una mejora en la calidad del sueño en 17\% de los maestros. Aunque no hubo diferencias en los horarios de sueño y la somnolencia, los resultados positivos refuerzan la necesidad de desarrollar programas educativos sobre el sueño con los maestros para difundir el tema en las escuelas y mejorar la calidad del sueño en estos profesionales.

Palabras clave: educación sobre sueño; calidad de sueño; somnolencia diurna; maestros; promoción de la salud. 
According to the International Classification of Sleep Disorders (American Academy of Sleep Medicine, 2005), disorders in the sleep-wakefulness cycle (SWC) may result from frequent changes in hours of sleep and wakefulness, either by changes in their regulatory mechanisms, or behavioral and social influences on these mechanisms. Thus, studies are being conducted to evaluate the effect of behavioral strategies on SWC in order to reduce rhythm disorders and improve sleep quality (Adachi et al., 2009; Cortesi, Giannoti, Sebastiani, Bruni, \& Ottaviano, 2004). Among the behavioral strategies are exposure to light (Revell et al., 2006), physical exercise (Montgomery \& Dennis, 2004) and sleep education programs (SEP). These programs have been conducted in adolescents at school (Cain, Gradisar, \& Moseley, 2011; Sousa, Souza, Louzada, \& Azevedo, 2013), adults at work (Kakinuma et al., 2010), elderly (Tanaka \& Tamura, 2016) and patients diagnosed with sleep disorders (Morin, 2004).

When evaluating the sleep knowledge of high school teachers, a low percentage of correct answers was observed in terms of individual differences, the temporal allocation of sleep and the duration required to maintain health and quality of life (Souza, Sousa, \& Azevedo, 2012a). The lack of knowledge about the consequences of harmful sleep habits may result in unsuitable habits close to bedtime, such as exposure to light, use of media and consumption of caffeine. These habits, combined with early school start times, can lead to sleep problems. In Brazil, most morning shift classes start around 7:00h. Moreover, teachers usually have extensive workloads (Decor et al., 2004) to increase their income (Reis, Araújo, Carvalho, Barbalho, \& Silva, 2006), which leads to a rise in extraclassroom activities such as class planning and corrections (Gasparini, Barreto, \& Asuncion, 2006). In addition, teachers face precarious conditions in public schools and increasing violence (Gasparini et al., 2006). These aspects could result in health problems (Landini, 2007).

Among the health problems, sleep problems are frequently reported by teachers. In a previous study, an average of 6.7 hours of time in bed was observed in Brazilian teachers during the week days, besides an extension of almost 42 minutes of this time on the weekend (Souza, Sousa, Belísio, \& Azevedo, 2012b). The extension of sleep on work-free days is characteristic of a compensation of sleep deprivation on working days. Others studies observed similar results pointing an average of 6 hours of sleep in teachers (Ferreira et al., 2010; Hermes \& Bastos, 2015; Vedovato \& Miller,
2008). Furthermore, Ferreira and collaborators (2010) showed that the few hours of sleep is associated with vocal fatigue, or weariness when waking up and Hermes and Bastos (2015) found that poor sleep quality is the principal cause of vocal illness.

Studies evaluating sleep quality in teachers and shift workers observed similar average of poor sleep quality, using the same instrument the Pittsburgh Sleep Quality Index (Almondes \& Araújo 2011; Souza et al., 2012b). Araújo et al. (2005) had found that $22.6 \%$ of teachers complained about drowsiness and $14.1 \%$ of insomnia. In another study, excessive daytime sleepiness was observed in half of the teachers (Souza et al., 2012b).

Sleep educational programs (SEP) have been used to improve sleep habits and reduce sleep problems. However, it is important to highlight that the effectiveness of educational programs in increasing knowledge does not necessarily entail behavioral changes. Therefore Moseley and Gradisar (2009) suggest that motivation is an important aspect to consider. Accordingly, Cain et al. (2011) applied a motivational interviewing strategy in a sleep educational program. This strategy aims to assist individuals in recognizing their problems and thereby increase motivation to change behavior. Despite the greater motivation of participants to regulate sleep times and increase sleep duration during the program, sleep patterns did not change after the SEP. This may be associated to difficulties in integrating several motivational elements, such as the sense of self-efficacy and positive attitudes toward the change in habits and the influence of society on the response of participants to the SEP (Cassoff, Knäuper, Michaelsen, \& Gruber, 2013).

In order to integrate the motivational components, Cassoff, Rushani, Gruber and Knäuper (2014) proposed a protocol in which a sleep intervention program incorporated: 1) motivational interviewing, 2) tailored intervention, to determine the most appropriate strategy to meet individual needs (Kreuter, 2003), and 3) stagebased intervention (Prochaska \& Velicer, 1997), which promotes improvements in health behavior, decisional balance and self-efficacy using stage-tailored content (Cassoff et al., 2014). Considering these issues, they used a model to predict that social influences and positives attitudes towards sleep are motivational factors associated to a higher intention to change sleep habits of participants. Moreover, these variables likely mediate awareness factors, thereby increasing the intention to change sleep habits (Cassoff, Gruber, Sadikaj, Rushani, \& Knäuper, 2014). 
According to Bluden and Rigney (2015), there are two specific types of SEPs: those that aim to disseminate information and those that seek to change sleeping behavior. The limitation in translating improved knowledge into behavioral change is attributed to numerous aspects of the programs applied in school settings, such as theoretical basis, teaching methodology, who deliveries the program, course content, program duration, tools used to measure sleep patterns, capacity to engage adolescents to participate in the program, contributing to their acceptance, motivation and willingness to change (Blunden, Chapman, \& Rigney, 2012; Bluden \& Rigney, 2015), and adolescents beliefs. Some of these beliefs are incompatible with scientific knowledge on sleep. Moreover, beliefs influence self- efficacy, i.e. self-assessment of the adolescents regarding their capacity to change their habits (Digdon, 2010). Nevertheless, participation in an SEP is associated with an increase in correct beliefs of adolescents (DíazMorales, Prieto, Barreno, Mateo, \& Randler, 2012).

Considering the necessity to apply an educational method that includes motivation, Sousa et al. (2013) evaluated a sleep education program based on the Meaningful Learning theory proposed by Ausubel (Ausubel, 1982). This theory proposes that meaningful learning occurs when new information relates to pre-existing knowledge on the cognitive structure of the learner (Ausubel, 1982), i.e., it is based on content contextualization. Thus, the participant actively relates previous knowledge to new one with teacher mediation. After the program, the adolescents increased sleep knowledge, decreased bedtime and wake up time irregularity, and showed a small increase in time in bed in the week, with a delay in wake up time and a tendency to go to bed earlier.

Considering that social times cause negative impacts on sleep, and that these losses may be greater in teachers due to the peculiar characteristics of the profession, it is very important that they acquire proper knowledge about sleep habits. This could contribute to them being better prepared to treat their own sleep problems and, in turn, disseminate this knowledge to their students. Thus, this study aimed to evaluate the influence of a sleep education program on the knowledge, habits, quality of sleep, and daytime sleepiness, in elementary and high school teachers.

\section{Methods}

The sample was defined for convenience and a total of 139 teachers were recruited to participate in the survey. They were informed about the methodology, and given an informed consent form. A total of 112 teachers returned the signed consent form and were asked to fill out the questionnaires. After all stages of the study, the final sample was composed by 40 female teachers ( $45.5 \pm 6$ years) from 25 public elementary and high schools in Natal, Northeastern Brazil. The experimental protocol was approved by the Research Ethics Committee of the Universidade Federal do Rio Grande do Norte (Protocol $=218 / 10$ ). Data collection was developed during two regular continuing education meetings for teachers, and consisted of three stages. The teachers that participated in the first meeting were evaluated between March to June of 2011 and those that participated in the second meeting, between May to August of 2012. The data collection did not coincide with end of the school year and vacations of the participants.

\section{Baseline (BL)}

From the 112 teachers, 84 filled out questionnaires at the BL and were asked to participate in the SEP. These questionnaires assessed about knowledge, habits, quality of sleep, daytime sleepiness and chronotype.

\section{Sleep Education Program (SEP)}

The 84 teachers were grouped in Experimental $(E G=58)$ and Control Group $(C G=26)$. The experimental group was composed of teachers that voluntarily participated in the SEP, while the Control consisted of those who for whatever reason were unable to attend the SEP meetings, and consequently, had not participated in the SEP, but were invited to participate in a future program.

The SEP was conducted during a course entitled "What to do to sleep better?", which consisted of four fortnightly meetings, lasting $4 \mathrm{~h}$ each. The didactic sequence was elaborated according to the theory of Meaningful Learning proposed by Ausubel, and discussed the following aspects of sleep: physiological and behavioral characteristics, mechanisms of regulation, functions, ontogenetic and individual differences and hygiene.

The lessons were taught using the dialogue exposure strategy and advanced organizers (AO). In this strategy, the lecturer makes questions about the subject and motivates the participants to verbally explain their conclusions, providing continuous interaction during the classes, making the lessons more attractive to the learners. The advanced organizers serve as a bridge between what the learners already know and what they 
should know, significantly facilitating learning (Ausubel, 1960). In this study, the advance organizers were based on the participants' prior habits and knowledge about sleep reported in the questionnaires filled at baseline, or their personal and professional habits reported during the classes, increasing motivation and encouraging them to learn. All the classes of the SEP were taught by the first author who is bachelor in Biology with teaching credentials.

$1^{\text {st }}$ CLASS. First, a discussion about teachers recent habits and their desire for change, as reported in the Sleep and Health questionnaire was used as an AO. Next, a practical activity was conducted to discuss the endogenous generation and the regulation of SWC by the external temporal cues, from everyday experiences. The sleep needs were discussed, pointing out to the individual differences in duration and preferential sleep times.

$2^{\text {nd }}$ CLASS. In this class, the physiological and behavioral characteristics of the SWC, and sleep functions were discussed. Furthermore, the teachers created posters reporting experiences about the short and long-term consequences of sleep deprivation for everyday life. This activity was an $A O$ for the discussion about the functions of sleep and the effect of sleep deprivation and irregularity on performance and health.

$3^{\text {rd }}$ CLASS. A practical activity where the teachers described the sleep schedules of individuals of different ages from their experiences in everyday life, was used as an $A O$ to discuss the ontogenetic differences in SWC and the importance of sleep knowledge in the school community. Reports of studies about the SWC in teenagers and teachers were used.

$4^{\text {th }}$ CLASS. In this class, a quiz showing the benefits of healthy sleep habits was used as an $A O$ to summarize the content of the previous classes. At the end of this lesson, teachers responded anonymously to a questionnaire that evaluated the SEP and stated their intention to change inadequate sleep habits, as well as the degree of difficulty they would face to achieve this goal. A booklet containing the contents of the program in simple and easy-to-understand language was handed out to all the teachers. In addition, a handout containing the practical activities throughout the course was given to the teachers that taught Science and/or Biology. The aim was to introduce concepts about biological rhythms and sleep in regular Science and Biology classes in elementary and high schools.

\section{Re-evaluation (REV)}

Three weeks after the last class to the EG, and 3 month after the baseline for both groups, teachers were re-evaluated by the questionnaires that assessed knowledge, habits and quality of sleep at baseline. Of the 84 teachers that received the questionnaires, only 26 (46 \pm 6 years) from the EG, and 14 ( $45 \pm 6$ years) from the CG, completed them, totaling 40 participants in the total sample. Teachers who attended at least $75 \%$ of the SEP classes or $50 \%$ of the classes and the final lecture were included in the EG. This last criterion was established because the last class discussed adequate sleep habits, and summarized the concepts of previous lessons.

Daytime sleepiness and chronotype were evaluated at baseline by the Epworth Sleepiness Scale (Johns, 1991) and the Horne and Östberg (1976) questionnaire (adapted for the Brazilian population by Benedito-Silva, Menna-Barreto, Marques, \& Tenreiro, 1990). The following aspects were assessed at baseline and re-evaluation: 1) Sleep knowledge and habits by the Health and Sleep questionnaire (Mathias, Sanchez, \& Andrade, 2006), adapted for teachers; 2) Bedtimes and wake up times, the type of awakening and the level of sleepiness upon awakening by the sleep diary for 10 consecutive days; and 3) Sleep quality by the Pittsburgh Sleep Quality Index (Bussey, Reynolds, Monk, Berman, \& Kupfer, 1989).

SEP methodology and the intention of changing habits was evaluated by 5 objective questions about the activities carried out during the program, and the level of contribution of these activities to learning and changing behaviors. Also, 7 objective questions assessed the intention of participants to change habits that hinder sleep. Participants could respond: 1) I do not plan to change, because I have always been doing that or I have no desire to, 2) I need to change, 3) I will try to change, but it will be difficult and 4) I will change.

\section{Data analysis}

Sleep knowledge was assessed by the percentage of correct answers in 20 true-false-l do not know questions, which were subsequently divided into 7 categories: 1) Consequences of sleep deprivation, 2) Sleep physiology, 3) Importance of sleep schedules, 4) Importance of napping, 5) Substances and activities that influence sleep, 6) Duration of sleep, and 7) Influence of light on the sleep schedule. The frequency of hits, misses and "I do not know" alternatives by group for 
each question was compared between baseline and reevaluation by the chi-square test. Moreover, the difference in the number of these alternatives between stages in each group was compared using the T test.

Qualitative analysis was conducted using an open question from the SEP evaluation questionnaire. This analysis was based on the content method using a qualitative approach that seeks to discover "the units of meaning" that make up the communication whose presence or frequency of appearance may be significant for analytical objective (Bardin, 2011). This analysis was carried out by the first author, who read the teachers comments and suggestions, recording the elements that appeared most frequently. These elements were then grouped as categories of analysis, which, according to Duarte (2004), can be determined in advance or emerge during identification of recurring content. Sleep habits, quality, and sleepiness level upon awakening were compared between baseline and reevaluation using the chi-square, while time in bed, bedtimes and wake up times, as well as irregularity in SWC (the standard deviation of bed and wake up times recorded in the sleep diary) were compared by ANOVA.

\section{Results}

The teachers were motivated and took active participation in the SEP, especially in practical activities used as advance organizers, sharing their personal and professional experiences. The SEP was evaluated by them as good (50\%) to excellent (50\%), among the options: bad, poor, fair, good or excellent. They reported (96\%) that the program enhanced their learning. The favorite aspects for most teachers were: the dialogic classes (67\%), slides (65\%) and practical activities (62\%).

In regard to the contribution of the SEP to changing habits, $64 \%$ of teachers reported that the program contributed significantly, because, in addition to learning about the SWC, they would follow many of the "sleep hygiene" measures, while $32 \%$ considered that the program could help in some way to change their behavior, and would try to follow some of the measures. Teacher feedback about the course is presented in Table 1.

\section{General Sample Characteristics}

Most of the characteristics of the sample did not differ between the groups. The teachers have children $\left(\mathrm{EG}=66 \%, \mathrm{CG}=57 \%-X^{2}=1.92 ; p=0.16\right)$, teach in 1 or 2 schools ( $E G=78 \%, C G=84 \%-X^{2}=1.19 ; p=0.27$ ), and in 1 or 2 shifts ( $E G=88 \%, C G=93 \%-X^{2}=1.61 ; p=$ 0.43).The majority were classified as intermediate type ( $E G=50 \%, C G=46 \%-X^{2}=0.04 ; p=0.83$ ) and exhibited excessive daytime sleepiness ( $E G=56 \%, C G=57 \%-X^{2}$ $=3.69 ; p=0.15)$. The average teaching time was $22 \pm 7$ years for the EG and $18 \pm 10$ years for the GC (T-test $t=$ $1.25, p=0.05$ ).

\section{Sleep Knowledge}

In the $3^{\text {rd }}$ stage, $15(75 \%)$ and $12(60 \%)$ of the 20 questions showed changes in the EG and CG, respectively $\left(X^{2}, p<0.05\right)$. The percentage of hits after the SEP increased in the 15 questions in the EG resulting in a decrease in the percentage of "misses" and "I do not know" $\left(X^{2}, p<0.05\right)$. The categories that showed the best results were: the use of substances and activities that influence sleep, the individual and ontogenetic differences in sleep duration, and the influence of light on sleep time. With respect to the CG, the percentage of hits increased in only 9 of the 12 questions $\left(X^{2}, p<0.05\right.$ - Figure 1). Furthermore, the number of hits increased in the EG compared to the CG (T-test $t=2.01, p=0.05$ ).

\section{Habits and Eating Before Bedtime}

In the $3^{\text {rd }}$ stage, drinking more than two glasses of water $\left(X^{2}=10.49 ; p=0.01\right)$ and coffee $\left(X^{2}=7.01 ; p<\right.$ $0.01)$ near bedtime decreased in the experimental group (Table 2), while soda consumption $\left(X^{2}=16.66 ; p<0.01\right)$ and physical activity $\left(X^{2}=7.69 ; p<0.01\right)$ near bedtime increased in the CG. Most teachers in both groups reported having a light snack $(H L S),\left(X^{2}=0.33 ; p=0.56\right)$ or drinking a glass of milk (DGM, $\left(X^{2}=2.70 ; p=0.10\right)$ near bedtime, with no differences between stages [EG $\left(H L S-X^{2}=0.21 ; p<0.64-D G M-X^{2}=0.84 ; p=0.77\right) ; C G$ $\left.\left(H L S-X^{2}=2.22 ; p=0.13-D G M-X^{2}=3.03 ; p=0.08\right)\right]$.

\section{SWC Pattern}

Bedtimes $\left(F_{(1,24)}=2.19 ; p=0.15\right)$, wake up times $\left(F_{(1,24)}=3.10 ; p=0.09\right)$, time in bed $\left(F_{(1,24)}=1.17 ; p=\right.$ 0.29 - Figure 2 ), as well as wake up time irregularity [EG $(B L=01: 09 \pm 00: 36 \mathrm{~min} ; \mathrm{REV}=01: 01 \pm 00: 38 \mathrm{~min})-\mathrm{CG}$ $(\mathrm{BL}=00: 56 \pm 00: 26 \mathrm{~min} ; \mathrm{REV}=1: 05 \pm 00: 26 \mathrm{~min})-\left(F_{(1,26)}\right.$ $=2.10 ; p=0.15)]$ and bedtime irregularity $[\mathrm{EG}(\mathrm{BL}=$ 01:01 \pm 00:29 min; REV = 00:48 \pm 00:23 min) - CG (BL = 01:07 \pm 00:34 min; $\operatorname{REV}=00: 55 \pm 00: 30 \mathrm{~min})-\left(F_{(1,26)}=\right.$ $0.04 ; p=0.94)$ ], did not differ between stages in either groups. Furthermore, type of awakening [EG $\left(X^{2}=0.50\right.$; $\left.p=0.77) ; C G\left(X^{2}=3.99 ; p=0.13\right)\right]$ did not differ during 
Table 1. Categories Representing the Feedback of the Teachers Regarding the Course Obtained from the Questionnaire of Evaluation about the Sleep Education Program.

\begin{tabular}{lcc}
\hline CATEGORIES & ABSOLUTE FREQUENCY & EXAMPLE \\
\hline Quality of the course & 10 & "Very interested and must be applied to the workers at school" \\
Course offer continuity & 7 & "Bigger dissemination of the extension program to other groups of teachers" \\
$\begin{array}{l}\text { Contribution to learning } \\
\text { Contribution to the health and quality of life }\end{array}$ & 4 & "It was great, because I got so much information and I have learned a lot" \\
Influence on the habits in daily life & 2 & "It is very useful to obtain a better condition of well-being and health for all" \\
\hline
\end{tabular}
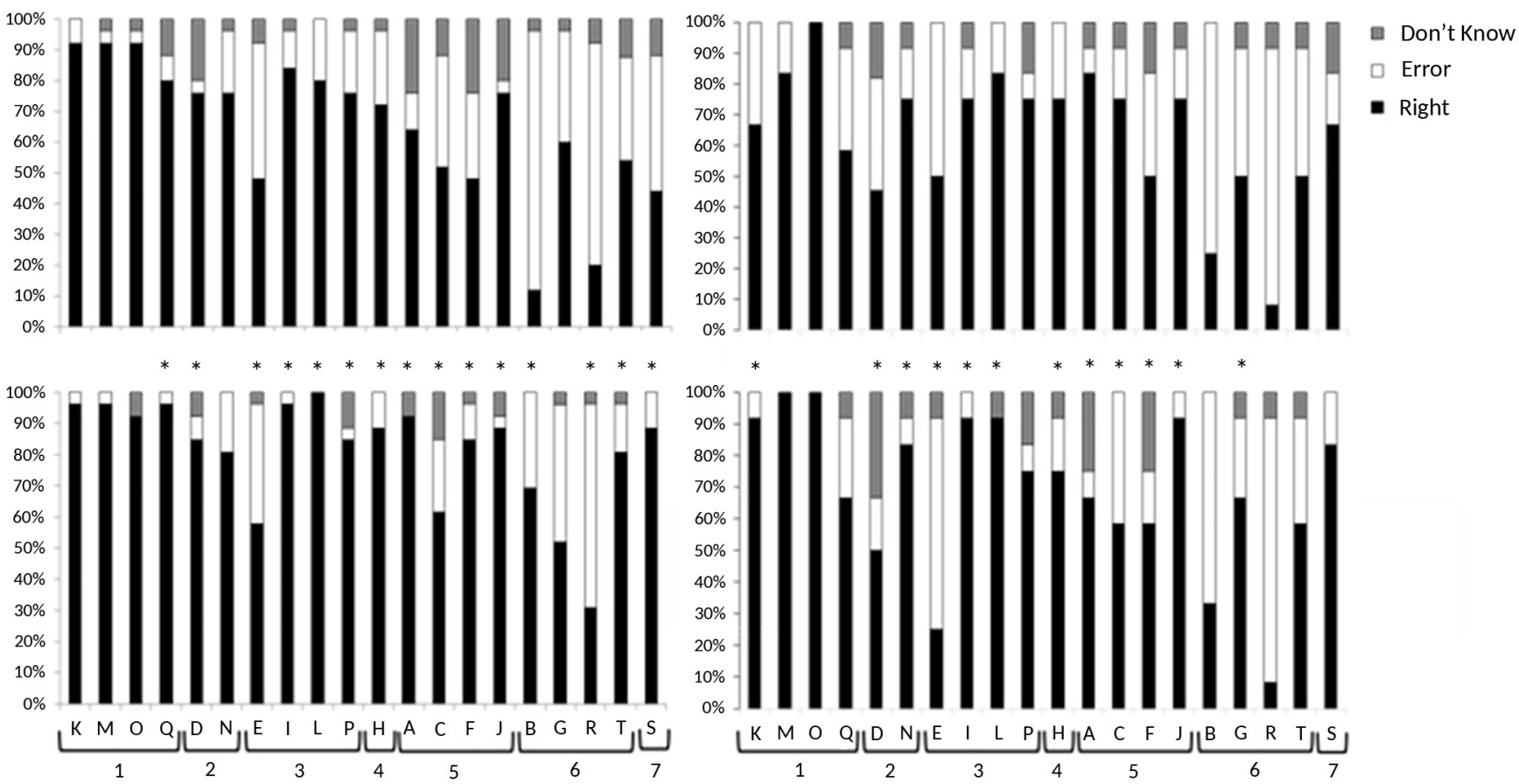

Figure 1. Percentage of "Don't know", "Error" and "Right" on Questions of Teachers of Experimental and Control Groups on the $1^{\text {st }}$ Stage (above) and $3^{\text {rd }}$ Stage (below). ( ${ }^{*}$ Differences Between Stages, Chi-square $p<0.05$ ). Categories: 1. Consequences of Sleep Deprivation: K, M, O, and Q; 2 . Sleep Physiology: D and N; 3. Importance of Sleep Schedules: E, I, L and P; 4. Nap Importance: H; 5. Substances or Activities that Influence sleep: A, C, F and J; 6. Sleep Duration: B, G, R and $\mathrm{T}$; and 7. Influence of Light on Sleep Schedules: $\mathrm{S}$.

the week. However, there was a small increase in EG teachers who reported waking up by themselves on the weekend $\left(X^{2}=9.95 ; p<0.01\right.$ - Table 2$)$.

\section{Sleepiness Upon Awakening And Sleep Quality}

In the $3^{\text {rd }}$ stage, both groups reported an increase in waking up "neither alert nor sleepy" on week [EG $\left(X^{2}\right.$ $\left.=63.73 ; p<0.01) ; \mathrm{CG}\left(X^{2}=94.19 ; p=<0.01\right)\right]$ and on weekends [EG $\left(X^{2}=81.96 ; p=<0.01\right)$; CG $\left(X^{2}=26.18 ; p=\right.$ $<0.01)$ - Figure 3]. The percentage of teachers classified as having good sleep quality increased in both groups [EG $\left(X^{2}=13.33 ; p=<0.01\right)$; CG $\left(X^{2}=4.16 ; p=0.04\right)$ - Table 2], $17 \%$ in the EG and $9 \%$ in the CG.

\section{Discussion}

Sleep educational interventions are currently being applied increasing the knowledge of participants and contributing to proper sleep habits (Kakinuma et al., 2010; Morin, 2004; Moseley \& Gradisar, 2009; Sousa et al., 2013). However, only two studies involved teachers in sleep education programs. The first, in the United States, held a workshop with Science and Mathematics teachers with a focus on adolescent sleep (Azevedo et al., 2008). The second, in Australia, issuing a 50-page manual to teachers that discussed the variables influencing sleep, also focusing on adolescent sleep (Bluden et al., 2012). 
Table 2. Percentage of Habits Near to Bedtime, the Way to Wake up in Week and Weekend, and Sleep Quality According to Groups on the $1^{\text {st }}$ and $3^{\text {rd }}$ Stages.

\begin{tabular}{|c|c|c|c|c|c|c|}
\hline & \multicolumn{4}{|c|}{ EXPERIMENTAL GROUP } & \multicolumn{2}{|c|}{ CONTROL GROUP } \\
\hline & \multicolumn{2}{|l|}{$1^{\text {st }}$ STAGE } & \multicolumn{2}{|l|}{$3^{\text {rd }}$ STAGE } & \multirow[t]{2}{*}{$1^{\text {st }}$ STAGE } & $3^{\text {rd }}$ STAGE \\
\hline \multicolumn{6}{|c|}{ Habits next to the sleep schedule } & \\
\hline Drink coffee & $20^{*}$ & & $12^{*}$ & & 7 & 7 \\
\hline Drink tea (black or mate) & 4 & & 0 & & 0 & 0 \\
\hline More than 2 glasses of water & $32^{*}$ & & $19^{*}$ & & 43 & 36 \\
\hline Physical activity & 4 & & 8 & & $0^{*}$ & $7^{*}$ \\
\hline None of the above & 64 & & 69 & & $50^{*}$ & $64^{*}$ \\
\hline \multicolumn{7}{|c|}{ Eating habits next to the sleep schedule } \\
\hline Sleep hungry & 11 & & 19 & & 21 & 21 \\
\hline \multicolumn{7}{|l|}{ Way to wake up in week } \\
\hline Alarm clock & 34 & & 35 & & 25 & 34 \\
\hline Someone call & 9 & & 8 & & 16 & 15 \\
\hline Spontaneously & 57 & & 57 & & 59 & 51 \\
\hline \multicolumn{7}{|l|}{ Way to wake up in weekend } \\
\hline Alarm clock & 167 & & 177 & & 6 & 7 \\
\hline Someone call & 15 & $*$ & 7 & $*$ & 11 & 9 \\
\hline Spontaneously & 69 & & 76 & & 83 & 84 \\
\hline
\end{tabular}

${ }^{*}$ Chi-square, $p<0.05$.

Thus, this is a pioneer study on assessing the effect of a sleep education program on the sleep knowledge and habits of teachers.

This educational program was associated with an increase in correct answers to the questions about sleep knowledge, a similar finding to that observed in previous studies which evaluated sleep knowledge of adolescents (Cain et al., 2011; Moseley \& Gradisar, 2009; Sousa et al., 2013). This may indicate the acquisition of new knowledge through changing alternative conceptions, which are ideas present in society and reinforced by the media, but conflicts with scientific knowledge (Wandersee, Mintzes, \& Novak, 1994). For example, the well-described individual and ontogenetic differences in the amount of sleep required for well-being are largely unknown to the general public. Consequently, individuals that differ from the norm are usually seen as being lazy or having sleep disorders. This conception was overcome in most teachers from the experimental group, evidenced by the increase in hits from $12 \%$ to $70 \%$ for the statement "All people must sleep 8 hours per night".

By contrast, the control group showed an increase in hits in some areas, but a decrease in others. This improvement may be due to intrinsic learning existing when filling out the same questionnaire twice, or interest in the subject has aroused the curiosity of teachers in search of information after baseline. Nevertheless, this group showed an increase in misses or "I don 't know" in questions that assessed individual differences, the effect of substances and physical activity on sleep, and the importance of naps. These topics also exhibited a high percentage of misses in high school teachers (Souza et al., 2012a) and adolescents that did not participate in an SEP (Mathias et al., 2006; Sousa et al., 2013). 
EXPERIMENTAL GROUP

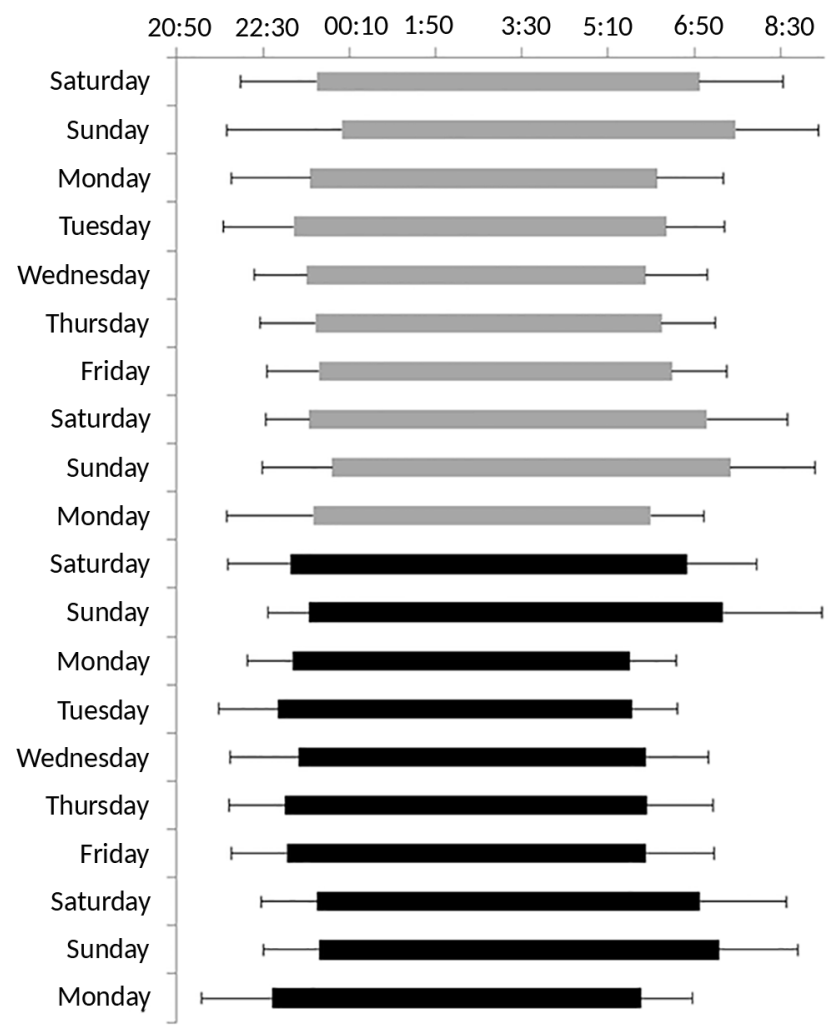

CONTROL GROUP

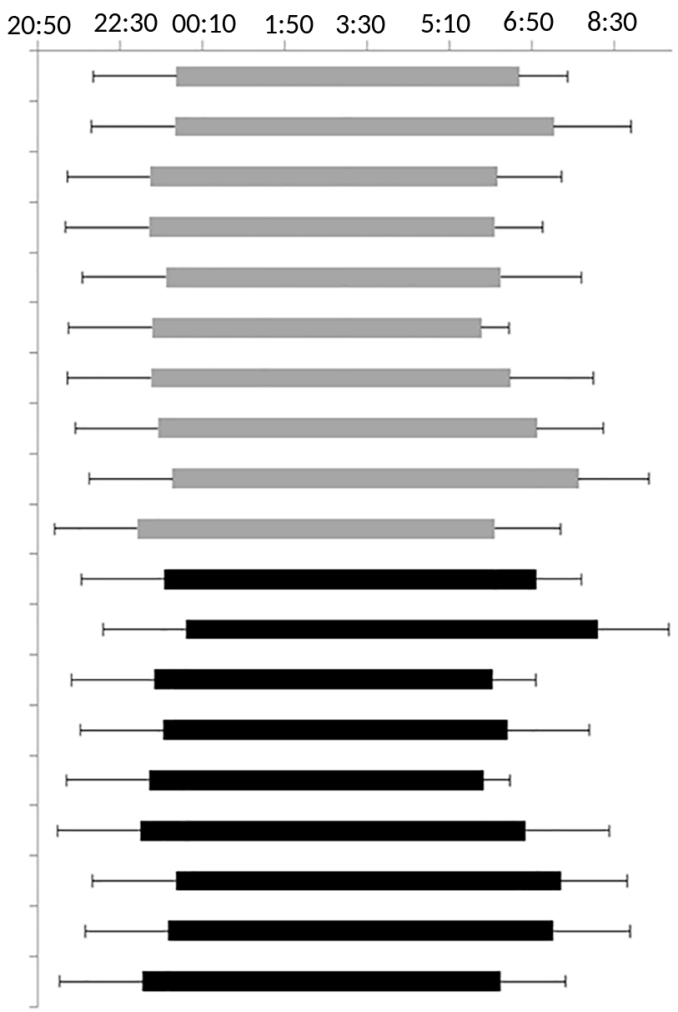

Figure 2. Wake Up Time, Bedtime and Time in Bed of the Teachers During 10 Days at the $1^{\text {st }}$ Stage (Gray Bars) and The $3^{\text {rd }}$ Stage (Black Bars) in Experimental and Control Groups (Mean And Standard Deviation). Anova, $p>0.05$.

EXPERIMENTAL GROUP

Weekdays
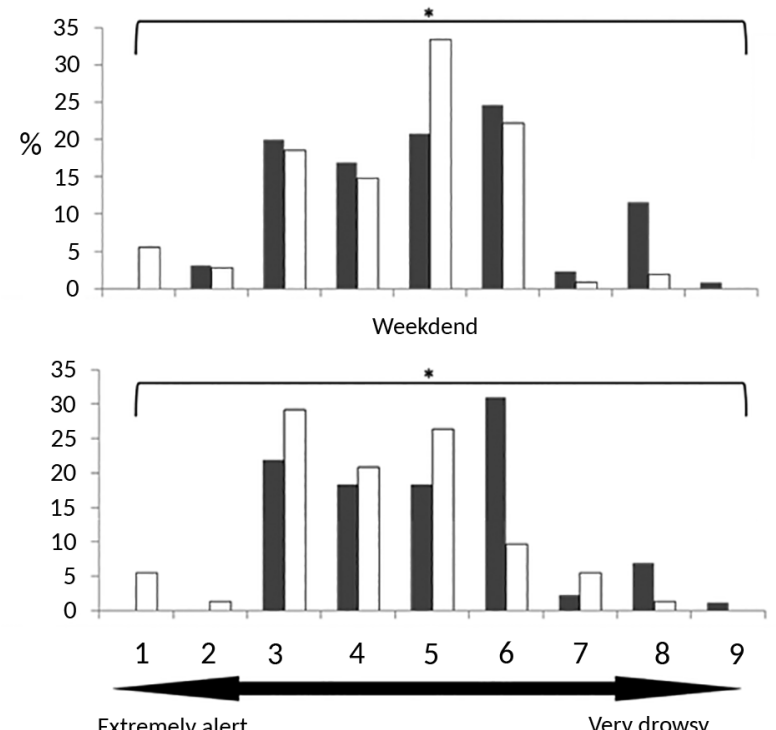

CONTROL GROUP

Weekdays
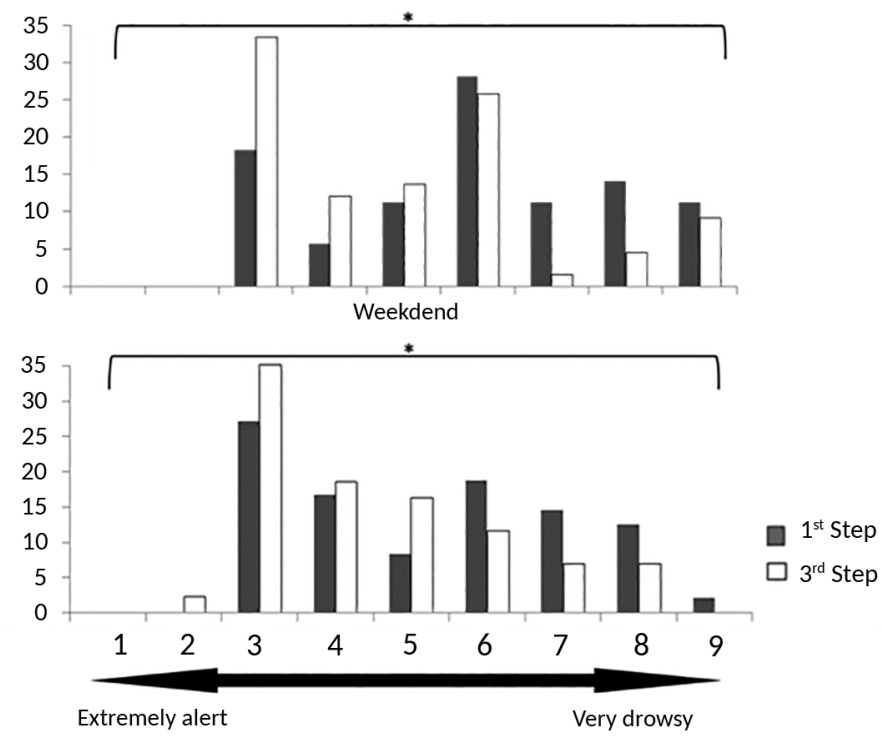

Figure 3. Percentage of Teachers Answering for the Sleepiness Level on Waking in Week and Weekend Days at The $1^{\text {st }}$ and $3^{\text {rd }}$ Stages in Experimental and Control Groups ( ${ }^{*}$ Differences Between Stages, Chi-Square Test, $p<0.05$ ). 
The increase in knowledge observed in the experimental group may have contributed to the decrease in coffee consumption near bedtime and the improved sleep quality in $17 \%$ of the teachers. Improved sleep quality was also observed in university students after a sleep education program (Brown, Buboltz, \& Soper, 2006). In the control group, $9 \%$ of teachers improved sleep quality in the re-evaluation, suggesting that other social or personal pressures are related to sleep quality. For example, Cropley, Dijk and Stanley (2006) examined the association between job strain and sleep quality in teachers from Unites Kingdom. They observed that poor sleep quality is more reported by teachers with high job strain compared with low job strain. In another study realized in Brazil, poor sleep quality was associated with physical and psychological symptoms of stress and sleep disorders in $46.7 \%$ of teachers (Valle, Reimão, \& Malvezzi, 2011). However, it is noteworthy that even before these pressures, the highest percentage of improvement occurred in the experimental group.

The positive results in the experimental group may be due to teacher motivation during the program, which may have contributed to changing their values and attitudes. This may be a result of the methodology used, which was based on the Meaningful Learning Theory, consisting of dialogic exposure and advance organizers. These strategies relate pre-existing with newly acquired knowledge, contextualizing the new information and relating it to daily life (Moreira \& Masini, 2001).

During the program, the teachers were highly motivated, participating in discussions, seeking to clarify doubts regarding habits present in everyday life, and sharing experiences, as evidenced by the comment: "I am putting it to practice already, and it is working". In addition, most participants positively evaluated the SEP and reported that knowledge would help them follow the sleep hygiene measures. They suggested that the program continue being offered to teachers, due to the importance of sleep for health and quality of life.

In spite of participation during the classes, the increase observed in sleep knowledge and the improvement in sleep habits, there were no changes in sleep patterns and sleepiness upon awakening. According to Blunden et al. (2012), changes in sleep patterns may not occur due to the methodology applied that do not consider the motivation element. Considering that the methodology used had obtained positive results when applied to adolescents (Sousa et al., 2013) and includes motivation as a primary factor, as was proposed by Moseley and Gradisar (2013), the changes in sleep schedules may not have occurred due to the characteristics of the teaching profession. Thus, even though the teachers reported an intention and willingness to get up later and go to bed earlier, they may not have changed behavior due to social influences (Cassoff et al., 2013), such as the need to comply with work schedules, time to perform extra teaching-related activities and daily tasks of parenting and housekeeping.

Furthermore, although the methodology applied in this study was effective in the learning process, some limitations should be noted. First, we did not consider individually tailored approaches (Cassoff et al., 2013); second, we did not evaluate motivational variables, such as self-efficacy and positive attitudes, which can contribute to the effectiveness of the program, or awareness factors (risk perception/action cues) that may increase the intention to change behavior (Cassoff et al., 2014); third, individuals differences that can exert important influences on sleep-wake patterns, such as chronotype (Díaz-Morales et al, 2012; Digdon, 2010), were not considered in the analyses due to the small sample obtained after all procedures of the study; and four, despite the data collection did not coincide with the end of the school year and vacations of the participants, it was not possible to rule out the influence of school evaluations period on sleep-wake cycle pattern.

Therefore, it is necessary to carry out further studies to assess motivational and awareness variables that can predict sleep behavior changes in teachers, including individually tailored approaches, and evaluate the influence of individual differences on sleep patterns or teachers workload on the effects of an SEP. In addition, to determining whether positive results could be obtained when the personal and professional demands of teachers are smaller, allowing a change in habits. However, it is important to underscore that the SEP is a challenge for teachers even when schools show interest in conducting the survey, and claim to know the importance of the subject. Teachers usually have a high workload and little free time for extracurricular activities which may have contributed to other limitations. First, performing the research in three stages may have resulted in $55 \%$ of the teachers failing to fill out the questionnaires; second, the difficulty to obtain similar size samples for both groups, since the contact with the control group was more difficult; and third, the difficulty to keep in touch with teachers for a longer interval precluded a long-term evaluation of the effects of the program. 
Therefore, it is important to evaluate the long-term effects of an SEP, as well as to conduct sleep programs during continuous education within the teachers 'regular workload. Besides the methodological contribution to the evaluation of the effects of a SEP on sleep patterns, this could enable teachers to acquire knowledge and methodological resources to address the subject in the classroom, thereby contributing to student awareness of proper sleep habits, empowering them to meet educational and social requirements, which undergo frequent changes.

In conclusion, the sleep education program was effective in increasing sleep knowledge, decreasing some inappropriate habits near bedtime and improving the sleep quality of teachers. However, it did not change sleep patterns or sleepiness upon awakening. Considering the positive results and the contribution of educational interventions in increasing knowledge and changing lifestyle, it is important to continue offering sleep training courses to teachers. This initiative may contribute to spreading knowledge about sleep in a school setting and to developing healthier sleep habits in teachers. The spreading of sleep knowledge at school may have future impacts on sleep habits of school communities, contributing to health and quality of life.

\section{Acknowledgments}

Special thanks are given to the teachers who participated in this research and to the schools' staff. We also thank Galileu Borges and Fernanda Kolodiuk for contribution in data collection. We acknowledge financial support from Coordenação de Aperfeiçoamento de Pessoal do Ensino Superior (CAPES) and Universidade Federal do Rio Grande do Norte.

\section{References}

American Academy of Sleep Medicine (2005). The international classification of sleep disorders: diagnostic \& coding manual (2nd ed.). Westchester, IL: Author

Adachi, Y., Sato, C., Nishino, N., Ohryoji, F., Hayama, J., \& Yamagami, T. (2009). A brief parental education for shaping sleep habits in 4-month-old infants. Clinical Medicine \& Research, 7(3), 85-92. doi: $10.3121 / \mathrm{cmr} .2009 .814$

Almondes, K. M., \& Araújo, J. F. (2011). Sleep quality and daily lifestyle regularity in workers with different working hours. Biological Rhythm Research, 42(3), 231-245. doi: 10.1080/09291016.2010.509480
Araújo, T. M. D., Sena, I. P. D., Viana, M. A., \& Araújo, E. M. (2005). Malestar docente: avaliação de condições de trabalho e saúde em uma instituição de ensino superior. Revista Baiana de Saúde Pública, 29(1), 6-21. Retrieved from http://inseer.ibict.br/rbsp/index.php/rbsp/ article/viewFile/108/pdf_528

Ausubel, D. P. (1960). The use of advance organizers in the learning and retention of meaningful verbal material. Journal of Educational Psychology, 51(5), 267-272. doi: 10.1037/h0046669

Ausubel, D. P. (1982). A aprendizagem significativa: a teoria de David Ausubel. São Paulo: Editora Moraes.

Azevedo, C. V. M., Sousa, I. C., Paul, K., MacLeish, M.Y., Mondéjar, M. T., Sarabia, J. A., ... Madrid, J. A. (2008). Teaching chronobiology and sleep habits in school and university. Mind, Brain and Education.2(1). 34-47. doi: 10.1111/j.1751-228X.2008.00027.x

Bardin, L. (2011). Análise de conteúdo (1st. ed., p. 279, L. A. Reto \& A. Pinheiro, Trans). São Paulo: Edições 70.

Benedito-Silva, A. A., Menna-Barreto, L., Marques, N., \& Tenreiro, S. (1990). A self-assessment for the determination of morningnesseveningness types in Brazil. In D. J. Hayes, J. E. Pauli, \& R. J. Reiter (Eds.), Chronobiology: its role in clinical medicine, general biology and agriculture (Part B, 1st. ed., pp. 89-98). New York: Wiley-Liss.

Blunden, S. L., Chapman, J., \& Rigney, G. A. (2012). Are sleep education programs successful? The case for improved and consistent research efforts. Sleep Medicine Reviews, 16(4), 355-370. doi: 10.1016/j. smrv.2011.08.002

Blunden, S. L., \& Rigney, G. A. (2015). Lessons learned from sleep education in school: A review of dos and don'ts. Journal of Clinical Sleep Medicine, 11(6), 671-680. doi: 10.5664/jcsm.4782

Brown, F. C., Buboltz, W. C., \& Soper, B. (2006). Development and evaluation of the sleep treatment and education program for students (STEPS). Journal of American College Health, 54(4), 231-7. doi: 10.3200/JACH.54.4.231-237

Bussey, D. J., Reynolds, C. F., Monk, T. H., Berman, S. R., \& Kupfer, D. J. (1989). The Pittsburgh Sleep Quality Index: a new instrument for Psychiatric Practice and Research. Psychiatry Research, 28(2), 193-213. doi: 10.1016/0165-1781(89)90047-4

Cain, N., Gradisar, M., \& Moseley, L. (2011). A motivational school-based intervention for adolescent sleep problems. Sleep Medicine, 12(3), 246-251. doi: 10.1016/j.sleep.2010.06.008

Cassoff, J., Gruber, R., Sadijak, G., Rushani, F., \& Knäuper, B. (2014). What motivational and awareness variables are associated with adolescent' intentions to go to bed earlier? Current Psychology, 33(2), 113-129. doi: 10.1007/s12144-013-9201-6

Cassoff, J., Knäuper, B., Michaelsen, S., \& Gruber, R. (2013). Schoolbased sleep promotion programs: effectiveness, feasibility and insights for future research. Sleep Medicine Review, 17(3), 207-214. doi: 10.1016/j.smrv.2012.07.001

Cassoff, J., Rushani, F., Gruber, R., \& Knäuper, B. (2014). Evaluating the effectiveness of the motivating teens to sleep more program in advancing bedtime in adolescents: a randomized controlled trial. BMC Psychology, 2(6), 1-10. doi: 10.1186/2050-7283-2-6

Cortesi, F., Giannoti, F., Sebastiani, T., Bruni, O., \& Ottaviano, S. (2004). Knowledge of Sleep in Italian High School Students: pilot test of a School-based Sleep Educational Program. Journal of Adolescent Health, 34(4), 344-351. doi: 10.1016/j.jadohealth.2003.07.003 
Cropley, M., Dijk, D. J., \& Stanley, N. (2006). Job strain, work rumination, and sleep in school teachers. European Journal of Work and Organizational Psychology, 15(2), 181-196. doi: 10.1080/13594320500513913

Decor, N. S., Araújo, T. M., Reis, E. J. F. B., Porto, L. A., Carvalho, F. M., Silva, M. O., ... Andrade, J.M. (2004). Condições de trabalho e saúde dos professores da rede particular de ensino de Vitória da Conquista, Bahia, Brasil. Caderno de Saúde Pública do Rio de Janeiro, 20(1), 187-196. doi: 10.1590/S0102-311X2004000100035

Díaz-Morales, J. F., Prieto, P.D., Barreno, C. E., Mateo, M. J. C., \& Randler, C. (2012). Sleep beliefs and chronotype among adolescentes: the effect of a sleep education program. Biological Rhythm Research, 43(4), 397-412. doi: 10.1080/09291016.2011.597620

Digdon, N. L. (2010). Circadian Preference and college students' beliefs about sleep education. Chronobiology International, 27(2), 297-317. doi: 10.3109/07420520903502895

Duarte, R. (2004). Entrevistas em pesquisas qualitativas. Educar em Revista, Curitiba, 24, 213-225. Retrieved from http://revistas.ufpr. br/educar/article/view/2216

Ferreira, L. P., Oliveira, M. D. R. D., Giannini, S. P. P., Ghirardi, A. C. D. A. M., Karmann, D. D. F., Silva, E. E., \& Figueira, S. (2010). Influence of abusive vocal habits, hydration, mastication, and sleep in the occurrence of vocal symptoms in teachers. Journal of Voice, 24(1), 86-92. doi: 10.1016/j.jvoice.2008.06.001

Gasparini, S. M., Barreto, S. M., \& Assunção, A. A. (2006). Prevalência de transtornos mentais comuns em professores da rede municipal de Belo Horizonte, Minas Gerais, Brasil. Cadernos de Saúde Pública, RJ, 22(12), 2679-2691. doi: 10.1590/S0102-311X2006001200017

Hermes, E. G. C., \& Bastos, P. R. H. O. (2015). Prevalência de sintomas vocais em professores da rede municipal de ensino de Campo Grande-MS. Revista CEFAC, 17(5), 1541-1555. doi: 10.1590/1982021620151751215

Horne, J. A., \& Österberg, O. A. (1976). A self-assessment questionnaire to determine morningness-eveningness in human circadian rhythms. International Journal of Chronobiology, 4(2), 97-110.

Johns, M. V. (1991). A new method for measuring daytime sleepiness: the Epworth Sleepiness Scale. Sleep, 14(6), 540-545. Retrieved from http://www.journalsleep.org/ViewAbstract.aspx?pid=24884

Kakinuma, M., Takahashi, M., Kato, N., Aratake, Y., Watanabe, M., Ishikawa, Y., ... Tanaka, k. (2010). Effect of brief hygiene education for workers of an information technology company. Industrial Health, 48(6), 758-765. doi: 10.2486/indhealth.MS1083

Kreuter, M. W. (2003). Community health promotion ideas that work (2nd ed.). Sudbury, MA: Jones \& Bartlett Publishers.

Landini, S. R. (2007). Professor, trabalho e saúde: as políticas educacionais, a materialidade histórica e as consequências para a saúde do trabalhador-professor. Colloquium Humanarum, 4(1), 8-21. doi: 10.5747/ch.2007.v04.n1
Mathias, A., Sanchez, R. P., \& Andrade, M. M. (2006). Incentivar hábitos de sono adequados: um desafio para os educadores. In S. Z. Pinho \& J. R. C. Saglietti (Eds.), Núcleo de ensino da Unesp (pp. 718-731). São Paulo: Universidade Estadual Paulista.

Montgomery, P., \& Dennis, J. (2004). A systematic review of nonpharmacological therapies for sleep problems in later life. Sleep Medicine Reviews, 8(1), 47-62. doi:10.1016/S1087-0792(03)00026-1

Moreira, M. A., \& Masini, E. F. S. (2001). Aprendizagem significativa: a teoria de David Ausubel (2nd ed.). São Paulo, Brasil: Editora Centauro.

Morin, M. (2004). Cognitive-Behavioral Approaches to the treatment of insomnia. Journal of Clinical Psychiatry, 65(16), 33-40.

Moseley, L., \& Gradisar, M. (2009). Evaluation of a school-based intervention for adolescent sleep problems. Sleep, 32(3), 334-341. Retrieved from http://www.journalsleep.org/ViewAbstract.aspx?pid=27406

Prochaska, J. O., \& Velicer, W. F. (1997). The transtheorical model of health behavior change. Journal of Health Promotion, 12(1), 38-48.

Reis, E. J. F. B., Araújo, T. M., Carvalho, F. M., Barbalho, L., \& Silva, M. O. (2006). Docência e exaustão emocional. Educação e Sociedade, 27(94), 229-253. doi: 10.1590/S0101-73302006000100011

Revell, V. L., Burgess, H. J., Gadza, C. J., Smiyh, M. R., Fogg, L. F., \& Eastman, C. I. (2006). Advancing human circadian rhythms with afternoon melatonin and morning intermittent bright light. The Journal of Clinical Endocrinology \& Metabolism, 91(1), 54-59. doi: 10.1210/jc.2005-1009

Sousa, I. C, Souza, J. C., Louzada, F. M., \& Azevedo, C. V. M. (2013). Changes in sleep habits and knowledge after an educational sleep program in 12th grade students. Sleep and Biological Rhythms, 11(3), 144-153. doi: 10.1111/sbr.12016

Souza, J. C., Sousa, I. C., \& Azevedo, C. V. M. (2012a). Conhecimento e hábitos de sono de professoras do ensino médio. In Associação Brasileira de Pesquisa em Educação e Ciências (Ed.), Anais do IIIV ENPEC. Campinas, SP. Retrieved from http://www.nutes.ufrj.br/ abrapec/viiienpec/resumos/R1174-1.pdf

Souza, J. C., Sousa, I. C., Belísio, A. S., \& Azevedo, C. V. M. (2012b) Sleep habits, daytime sleepiness and sleep quality of high school teachers. Psychology \& Neuroscience, 5(2), 257-263. doi: 10.3922/j. psns.2012.2.17

Valle, L. E. R. D., Reimão, R., \& Malvezzi, S. (2011). Reflexões sobre Psicopedagogia, estresse e distúrbios do sono do professor. Revista Psicopedagogia, 28(87), 237-245. Retrieved from http:// pepsic.bvsalud.org/scielo.php?script=sci_arttext\&pid=S0103$84862011000300004 \&$ Ing $=$ pt\&tIng=pt

Vedovato, T. G., \& Monteiro, M. I. (2008). Perfil sociodemográfico e condições de saúde e trabalho dos professores de nove escolas estaduais paulistas. Revista Escola de Enfermagem, USP, 42(2), 290-7. doi: 10.1590/S0080-62342008000200012

Wandersee, J., Mintzes, J., \& Novak, J. (1994). Research on alternative conceptions in science. In: D. L. Gabel (Ed.), Handbook of research on science teaching and learning (pp.177-210). New York: MacMillan. 
Jane Carla de Souza, Doutora em Psicobiologia pela Universidade Federal do Rio Grande do Norte (UFRN), é Professora da Faculdade de Ciências da Saúde do Trairi (FACISA/UFRN). Endereço para correspondência: Av. Santa Luzia, 236. Nova Parnamirim - Parnamirim RN. Telefone: (84) 98868-5570. E-mail: janebrjp@hotmail.com

Sabinne Danielle Galina, Licenciada em Ciências Biológicas pela Universidade Federal do Rio Grande do Norte (UFRN), é Mestranda do programa de Pós-graduação em Psicobiologia da Universidade Federal do Rio Grande do Norte (UFRN). E-mail: sabinneg@hotmail.com

Ivanise Cortez de Sousa, Doutora em Psicobiologia pela Universidade Federal do Rio Grande do Norte (UFRN), é Professora do Departamento de Fisiologia da Universidade Federal do Rio Grande do Norte (UFRN). E-mail: ivanise@cb.ufrn.br

Carolina Virginia Macêdo de Azevedo, Doutora em Neurociências e Comportamento pela Universidade de São Paulo (USP), é

Professora do Departamento de Fisiologia da Universidade Federal do Rio Grande do Norte (UFRN). E-mail: carolina@cb.ufrn.br

Recebido em 19.Fev.16

Revisado em 30.Jul.16

Aceito em 06.Out.16 